\title{
REFUSAL TO COMMUNICATE AS A POSITIVE AND NEGATIVE COMMUNICATION STRATEGY
}

\author{
Olga Leontovich and Marianna Gulyaeva
}

\begin{abstract}
The paper has an overall focus on the refusal to communicate, which naïve language users would often interpret as "zero communication". This aspect of human interaction has not yet been thoroughly investigated, which accounts for the novelty of the research. The paper analyses reasons for the refusal to communicate, its types, strategies, positive and negative effects, as well as verbal and nonverbal ways of its expression. The study uses a mixed-method research design based on observation, discourse analysis and method of introspection. The material of the research includes 389 acts of refusal to communicate selected from real-life or Internet conversations, fiction of the late $20^{\text {th }}$ - early $21^{\text {st }}$ centuries, and films in English and in Russian. All the communicative acts are investigated along the following lines: a) reasons; b) types; c) communication strategies; d) functions and e) forms of linguistic expression of refusal to communicate. We identify regularities and classify our data within each of the devised categories. The paper argues that refusal to communicate, which in fact manifests the intention to terminate communication, is part and parcel of human interaction possessing strong pragmatic, functional and emotional value. Though it is generally seen as a negative communication strategy, this study shows that under certain circumstances it can also have a positive effect on the outcome of interaction.
\end{abstract}

\section{Keywords}

refusal to communicate, "zero communication", positive and negative strategies, verbal and non-verbal forms of expression, outcome of interaction

\section{Introduction}

The present paper is part of a research project devoted to positive communication - "an interaction based on positive emotions, aimed at mutual understanding and satisfying for all the parties involved" (Leontovich 2014: 121). According to the research, key components of positive communication include: positive intentionality, initiative, adaptation to the interlocutor, empathic listening and social support.

The refusal to communicate is usually interpreted either as "zero communication" or a negative communication strategy, but we intend to prove that it is part and parcel of human interaction possessing strong pragmatic, functional and emotional value. We will analyse reasons for the refusal to 
communicate, its types, strategies, positive and negative effects, as well as verbal and nonverbal ways of its expression.

\section{Rationale for the study}

For our purposes, it is critical to reflect on the theoretical principles underlying the research. We share the approach of scholars who investigate communication "trying to connect ideas in new ways to the psychology, lived experiences, and self-fashioning of those who think them" (McMahon \& Moyn 2014: B12). The thrust of such efforts is in line with the view of discourse processing as "a dynamic process, involving the negotiation of meaning between the speaker and the hearer in the context of utterance" (Dontcheva-Navratilova \& Povolná 2012: ix).

Though numerous studies are devoted to different communication practices and mechanisms, we are not familiar with any works specifically addressing the refusal to communicate. The present paper explores this notion through the theoretical framework of discourse analysis (cf. Fairclough 2003, Philips \& Hardy 2002, Ponton \& Larina 2016, Van Dijk 2007) with the awareness of a variety of linguistic, social, cognitive and affective skills of interlocutors affecting the course of their interaction (Komlósi 2012).

According to the metacommunication axiom, a person cannot not communicate (Watzlawick et al. 2000). We proceed from the assumption that any human behaviour, including the refusal to communicate, is a form of communication. Our study is based on the following key ideas.

A. In an ideal scenario, communication is supposed to be a harmonizing activity, which presupposes joint efforts of its participants aimed at a common goal (Lemmerman 1999, Moskvin 2008). From this point of view, refusal to communicate can be seen as a violation of Grice's cooperative principle (Grice 1975), a symptom of constrained or even destructive interaction (Golovaha \& Panina 1989), a form of an insecure personality's self-protection (Bodalev 2011, Vygotskij 2003), an expression of negative attitude towards an interlocutor (Egides 2002), a face-threatening act (Brown \& Levinson 1987) or a manipulation technique (Egides 2002, Lamykin 2010).

B. Refusal to communicate can be caused by such factors as lack of interpersonal attraction (Egides 2002, Kunicyna et al. 2001), individual traits of character (cf. Bodalev 2011, McCroskey 1997) or low degree of social adaptability (Bippus \& Daly 1999, Burgoon 1991, Motley \& Molloy 1994, Vygotskij 2003).

C. Refusal to communicate is usually interpreted as a non-productive strategy of conflict resolution (Cloven \& Roloff 1991, DeVito 2001). However, under 
certain circumstances it can be effective (Verderber \& Verdeber 2003, Weaver 1996) and may prove to be culture specific (Leontovich 2002, Ting-Toomey \& Chung 2005).

D. Refusal to communicate can be expressed by explicit or indirect utterances, non-verbal actions as well as specific communication strategies (Dementjev 2006, Issers 2008).

\section{Research methodology and data}

The study involves a mixed-method research design (Tashakkori et al. 2003, Plano \& Creswell 2008) which includes: a) observation used to select primary data, clarify and interpret the results at the intermediate and final stages of the research; b) discourse analysis for the study of verbal and non-verbal interactions in a social context and c) method of introspection employed to investigate the causality of people's behaviour on the basis of the researchers' own communicative experience. The use of triangulation strategy provides for a greater accuracy of the findings.

The unit of analysis is a communicative act of refusal to communicate. Three hundred and eighty nine communicative acts were selected from: conversations observed in real life or obtained from the Internet (411 pages of scripts); fiction of the late $20^{\text {th }}$ - early $21^{\text {st }}$ centuries in English and in Russian ( 9,822 pages); 34 fiction films (total running time approx. 80 hours). Though communication in fiction and films is stylised, the use of these sources of practical material provided for a great variety of linguistic expression, situational contexts and personal identity of interlocutors. All the communicative acts were further investigated along the following lines: a) reasons; b) types; c) communication strategies; d) functions and e) forms of linguistic expression of refusal to communicate. The analysis allowed us to identify regularities and classify our data within each of the devised categories. We will further discuss our results on the basis of this categorization, keeping in mind that the examples which illustrate our findings only partially reflect the complexity of the interactions, as "the interplay of prior context and actual situational context, individual and social factors of communication are intertwined" (Kecskes 2014, as cited in Ponton \& Larina 2016: 9).

\section{Analysis}

\subsection{Reasons for refusal to communicate}

According to our data, objective reasons are caused by circumstances and force people to terminate communication irrespective of their desires. These include 
physical distance, social and political factors, interference of other actors, etc. Subjective reasons are produced by communicators themselves and are based on: a) people's motives in a particular interaction (attempt to avoid conflict, fear, wish to save face, desire to manipulate the interlocutor); b) individual characteristics (shyness, social awkwardness, aloofness, passivity, introversion, suspiciousness); c) communicator's emotional state (disillusionment, anger, fatigue, boredom); d) relationship between interlocutors (antipathy, disappointment, hurt feelings) and e) form of communication process itself (quality, quantity and relevance of shared information, tone and style of interaction, asymmetry and disbalance between interlocutors).

\subsection{Types of refusal to communicate}

\subsubsection{Deliberate / indeliberate refusal}

Deliberate refusal takes place when people consciously declare their intentions. This is an informed decision aimed at a particular result. Indeliberate (unconscious) refusal is spontaneous; people do not explicitly formulate their desire to terminate communication. Such refusal is often impulsive, stimulated by sudden emotions, causing an unexpected communication breakdown and is often expressed non-verbally.

\subsubsection{Explicit / implicit refusal to communicate}

Explicit refusal is a locutionary act, a direct utterance denoting the desire to terminate communication, e.g. Shut up! Just leave! Be off with you! or a more polite but still perspicuous form of expression, like in the following conversation between two women involved in a conflict during a dancing competition, when one of them is trying to resolve the conflict, while the other is unwilling to talk:

$$
\begin{aligned}
& \text { "I wanted to talk to you." } \\
& \text { "I am not in a good mood. You'd better leave." (source: from observation) }
\end{aligned}
$$

Implicit refusal is expressed indirectly; the partner is expected to infer the real meaning through reasoning, understanding of the situation and presuppositions:

(2) $\quad<\ldots>$ Abbie said she needed to do some work and was going to head for the dorm. Hacker offered to drop her off but she said she wanted to walk. (Evans 2005) 


\subsubsection{Permanent / temporary refusal}

Permanent refusal presupposes that communicators intend to utterly break the relationship with the interlocutors and exclude them from their social network. It is not necessarily expressed in words - communicators may avoid their partners in the hope that they will understand their unwillingness to sustain the relationship, as in the following situation:

She wiped her eyes one final time and closed her purse.

"I don't want you to contact me again $<\ldots>$."

"Katie- - "

"I mean it. Don't email me, don't call me. Ever." (Evans 2005)

Temporary refusal denotes the person's unwillingness to communicate in a particular situation, the wish to suspend the interaction for a certain period of time. Later, after the crisis is over, the relationship can be renewed. In the following example the girl does not want to communicate with her father because he had left her mother for another woman, but she does not see this situation as permanent:

(4) Three or four times a week he would call her cell phone but she usually just let it ring and then listened to his message <...> And sometimes, just to get him off her back, she would take the call and say coldly that she was really busy and no, sorry, it wasn 't convenient for him to come, nor that weekend, nor any other foreseeable. She didn't know how long it would be before she would stop wanting to punish him. $<\ldots>$ The fact that she missed him terribly only stoked it further. (Evans 2005)

\subsubsection{Refusal proper / pseudo-refusal / quasi-refusal}

These types differ from the point of view of the conveyed meaning and illocutionary force.

Refusal proper pursues a real aim - to deny communication or terminate it, e.g. I don't want to talk. Leave me alone. We have to separate.

Pseudo-refusal takes place when the communicator's aim is different from what is said, i.e. the locutionary and illocutionary effect of the utterance do not coincide: on the surface it expresses the desire to end the interaction, but in reality it is manipulative and pursues different goals. When a girl flirting with a guy says: Leave me alone, it can actually mean that she wishes to continue to communicate. Our material shows that pseudo-refusal may be an attempt to initiate an acquaintance or an argument, be a form of coquetry or manipulation, 
demonstrate that a person is hurt, amazed, indignant, etc. The contexts below illustrate some 'cool' forms of flirting:

(5) Boy: Haven't I seen you some place before?

Girl: Yes - that's why I don't go there anymore.

(6) Man: Your place or mine?

Woman: Both. You go to yours, and I'll go to mine.

(7) Man: Hey baby, what's your sign?

Woman: Do not enter.

(8) Man: I'd go through anything for you.

Woman: Good! Then you can start by going through the door. ("Flirting Quotes, Sayings, Pick-up Lines", 2016)

Quasi-refusal is the communicator's illusion that the interaction is terminated whereas in reality it is continued. The absence of verbal exchange does not mean that there is no communication, though naïve language users often get such an impression, as in the following Russian joke:

(9) A husband comes home after work. His wife meets him with a poster: "I am not talking to you". The husband goes to the living room and sits down to watch TV. The wife comes in with a new poster: "And do you know why?" (source: Family Jokes)

The difference between pseudo-refusal and quasi-refusal is that in the first case communicators intentionally use refusal to communicate to achieve their goals, whereas in the second case they sincerely believe that they have terminated communication, which is not true.

\subsection{Communication strategies}

The strategy of communication denial involves such tactics as avoidance, use of silence, explanation of reasons why communication is unwelcome, as well as disregard of the interlocutor.

The strategy of withdrawal includes disqualification of communication or passive speech behaviour. Disqualification is achieved by means of violating the logical coherence of communication, contradictory utterances, feigned incomprehension, etc. When Deborah, one of the main characters of the film Spanglish (2004), tells her husband John that she had an affair with another man, he pretends not to hear her. Passive speech behaviour is characterised by 
long pauses between utterances, curt responses, awkward silence, inattentive listening, etc.

Whereas the former strategies correlate with an implicit refusal to communicate, overt communication break is an explicit strategy used to interrupt a conversation in an assertive, discretionary, polite or rude and abrupt manner, with or without explanation of motives, use of insults, threats, etc. In the following real-life situation, Kate is at her new working place where her colleagues are not willing to accept her. She tries hard to integrate in the office environment but is met with tension and irritation. Every time she asks colleagues for assistance, the reaction is: "I am too busy to help you" or just: "What?" in a voice full of irritation and eyes rolling.

The choice of strategies depends on the interlocutors' communication competence and their ability to employ cooperative and politeness principles. However, in certain cases even skilful communicators can intentionally disregard them if they want to end a conversation, terminate a relationship or vent their emotions.

\subsection{Verbal and non-verbal forms of expression}

Verbal resources used to express the refusal to communicate can convey a variety of feelings and moods. Mild forms of expression are employed to spare the interlocutor's feelings, like in the context below:

(10) It's unfair on my part and would be unfair to you to continue our relationship if one of us had to fake it. $<\ldots>$ It would be cheating you if I were to pretend I felt this way and would cause more heartache if I continue to do so. I think it would be wise if we stopped seeing so much of each other. (Canary et al. 1994)

The mitigating effect can be achieved through the use of:

- neutral vocabulary devoid of negative connotations;

- interrogative constructions with a hint at the unwillingness to pursue the relationship;

- subjunctive mood reducing the impact of unpleasant messages;

- interrogative forms indicating the communicator's doubts and hesitations;

- polite phrases expressing remorse, regret and apologies;

- modal constructions emphasising the subjective assessment of the situation, etc.

The harshness of the refusal grows with the use of:

- negative sentences expressing disagreement: I can't talk about it anymore. Never want to see you again. I'll never forgive you. 
- sharp imperative constructions: Shut up! Never come back! Get lost!

- derogatory statements, accusations and outright insults: Get out of here, you jerk!

The paralinguistic (or paraverbal) elements which accompany speech (intonation, loudness of voice, whisper, laughter, weeping, etc.) can account for a variety of emotional shades of the same utterance, from polite to rude, from strict and abrupt to gentle or pleading. Long pauses can denote the unwillingness to communicate. The rhythm and tempo of speech can indicate enthusiasm or indifference, as well as regulate the degree of finality of the refusal to communicate, as in:

"We can't talk here," she said, glancing around nervously. "Can't I see you tomorrow," she pleaded.

"That's always the problem," he said disgustedly. And at that moment she knew he was going to break up with her. (Bushnell 2003)

Prosody can emphasize the prominence of the message:

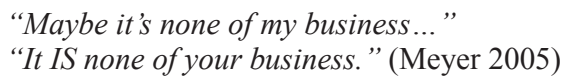

Refusal to communicate also utilises numerous nonverbal clues. On the level of body language communicators knock their fingers on the table, tap their feet on the floor, acquire a defensive position, put their hands in pockets, touch their face, put their forefinger to their lips (Silence!), turn their backs on the partners, brush them aside, etc.

Mimics (facial movements) can express lack of interest, irritation, disappointment, disgust, despair, etc. Oculesics (eye behaviour) may be represented by: eye aversion from an obtrusive interlocutor, demonstratively closed eyes when the communicator is not inclined to engage in a conversation or avoidance of eye contact, as in the context below:

$$
\begin{aligned}
& \text { "Maybe we can catch up properly later? With the others?" } \\
& \text { "Uh-yeah." Fi nods without looking me in the eye. } \\
& \text { Why is she being so off? What's wrong? (Kinsella 2011) }
\end{aligned}
$$

Haptics (touching) is more often used to establish contact rather than terminate it. The exception is only pushing off the interlocutor or using violence. Widely used are deliberate or indeliberate rejections of touching, handshakes, embraces and kisses: 
(14) He walked over and came up behind her and tried to put his hands on her shoulders but she violently shrugged him away. "Don't touch me." (Evans 2005)

The avoidance of touch is closely connected with proxemics: longer, non-typical distance between communicators can be a signal of unwelcome interaction: Don't come up to me! Stay away from me! Back off! Sometimes when people refuse to communicate, they move away from each other or turn their back on the interlocutor; when spouses fall out, they often sleep in different rooms.

Sometimes people cannot openly admit that they do not wish to communicate, but their non-verbal actions betray the intention:

She mustn't let him get away, she thought; and yet, the way he was shifting his feet seemed to indicate that he was longing to escape from her. (Bushnell 2003)

Total avoidance is the extreme case described below:

(16) I wouldn't say anything, I would just avoid a person as much as possible. Without explaining my intentions to break it off, I would avoid scheduling future meetings with the person; I would just never call the person again and never return any phone calls. (Canary et al. 1994)

Verbal and non-verbal elements can be used in combination to reinforce the message or contradict each other revealing the communicators' true intentions.

\subsection{Positive and negative functions of refusal to communicate}

Communication is viewed as a natural mode of human existence; therefore refusal to communicate is usually regarded as a negative phenomenon. It violates the smooth flow of interaction or denotes a permanent break-up of a relationship, as in the context below:

"How convenient, Lara, I don't have time for this."

"Ed, please." My eyes are welling up. "You have to believe me..."

"Bye, Lara." (Kinsella 2010)

It can also be used as a manipulation technique implying psychological and emotional pressure on the partner(s), as in the following example:

When I'm offended I just stop talking to my husband till he realizes he hurt me and apologizes. 
In another conversation, Grandmother refuses to communicate after someone breaks her teapot. Her real aim is to attract attention to her own persona and make everybody feel guilty:

\footnotetext{
"Nina, what's the matter?" Grandpa asked gently.

"Really, Grandma, don't you have enough teapots? We'll buy you a new one, even better," I tried to calm her down.

"Leave me alone. Let me die in peace".

"Nina, what's up?" Grandpa said $<\ldots>$ Because of the teapot... Why?"

"Leave me alone... Just leave me, I am not bothering you... My life is broken, it's not about the teapot..." (Sanayev 2015)
}

This kind of behaviour does not contribute to the basic principles of positive communication but it is rather directed towards acquisition of personal benefits and power.

Negative verbal and nonverbal forms of expression include the use of insults, rude, sharp and cruel expressions, as well as physical violence.

However, contrary to common opinion, refusal to communicate may fulfil a number of positive functions.

The etiquette function is realised when an interaction is interrupted for reasons of courtesy. It can be employed as a positive politeness strategy when a communicator is afraid to be obtrusive or impolite and therefore feels an obligation to say goodbye:

(20) Then Ed glances at me, and my empty glass, and says, "Don't let me keep you".

Don't let me keep you. It's a good thing I'm not into this guy. <...> I don't know what it is.

"I'm sure you have dinner plans," he adds politely.

"Yes!" I say brightly. "I do as it happens. Absolutely. Dinner plans." I do a pantomime sweep of my watch in front of my eyes. "Goodness, is that the time? I must run. My dinner companions will be waiting."

"Well, I have plans too." He nods. "So maybe we should..."

"Yes, let's. It's been fun." (Kinsella 2010)

The wait-and-see function of refusal to communicate is fulfilled when a person wishes to wait through an unfavourable or inappropriate period until the partner is in a good disposition and ready for an effective dialogue. An example can be a conflict situation in which one of the communicators is trying to avoid an argument. When emotions subside and both partners are ready to sort things out, the interaction can be resumed. This is illustrated by a woman's confession about her family life: 
(21) Yes, we have some discordance with my husband, but who doesn't? But I try to avoid a real quarrel because afterwards I always regret saying something. And I really do not want to offend the person I love. In this case I just keep silent and it can last from several minutes to several days. And then when I feel I've cooled down I initiate a calm conversation. (source: from observation)

The protective function is realised when refusal to communicate acts as a form of defence from the outside world, obtrusive interlocutors, violation of personal privacy, as well as when the communicator feels fear, uncertainty or shyness. In certain situations, all communication channels are blocked for the sake of protection from the social environment. In the film Kramer vs. Kramer (1979) Ted, the main character, is completely devastated by the court decision, which enforces him to give his son away to his wife. In order to get over the shock, he locks the door and does not respond to his neighbour's attempts to reach him. This function can generally be seen as positive, but potentially holds the danger of isolation from the outside world.

The regulative function coordinates the behaviour of communicators and the basic principles of their interaction. It usually includes a metalinguistic commentary. For example, in the film In the Land of Women (2008) the daughter does not want to talk to her mother as she is not pleased with the topic of the discussion and form of interaction:

"Mom, I can't talk about it anymore. $<\ldots>$ And I really don't want to fight with you right now." (English 2008)

The analysis shows the dichotomy between positive and negative functions of the refusal to communicate and proves that its competent use can significantly contribute to positive communication.

\section{Conclusion}

This research highlights the most important features and mechanisms of refusal to communicate and allows us to make the following conclusions:

1) refusal to communicate is not 'zero interaction', but rather an important constituent of communication process;

2) the types of refusal to communicate include: deliberate and undeliberate refusal; explicit and implicit refusal; temporary and permanent refusal; refusal proper, pseudo-refusal and quasi-refusal;

3 ) the main strategies of refusal to communicate are: communication denial involving the tactics of avoidance, use of silence, explanation of reasons 
why communication is unwelcome, disregard of the interlocutor; withdrawal including disqualification of communication or passive speech behaviour; and overt communication break;

4) verbal and non-verbal forms of expression can be employed to achieve a harsh or a mitigating effect during the act of refusal from communication;

5) negative functions of the refusal to communicate are: a) that it violates the basic principle of communication - to unite people; b) it can be used as a means of manipulation, which implies a deliberate and purposeful influence on the interlocutor to one's own advantage; c) it can involve the use of insults, rude, sharp and cruel expressions, as well as physical violence;

5) its positive effect is achieved through the etiquette function, wait-and-see function, protective function and regulative function realised by means of different verbal and non-verbal recourses including silence, the use of which largely depend on the interlocutors' communicative competence.

This study can be extended in several ways. Useful insights could be generated from examining the interplay between refusal from communication proper, pseudo-refusal and quasi-refusal; revealing the linguistic and non-linguistic markers of constructive and destructive use of refusal from communication; opportunity to work out strategies of behaviour on the basis of its negative and positive functions. The contemporary critical environment also provides fertile ground for the investigation of its culture-specific dimensions.

\section{Acknowledgements}

The research is supported by grant № 16-34-00016 of the Russian Foundation for Humanities.

\section{References}

Bippus, A. and Daly, J. A. (1999) 'What do people think causes stage fright? Naive Attributions about the reasons for public speaking anxiety.' Communication Education 48, 63-72.

Bodalev, A. A. (2011) Psihologija obshhenija [Psychology of Communication]. Moscow: Kogito centre.

Brown, P. and Levinson, S. C. (1987) Politeness: Some Universals in Language Usage. Cambridge: Cambridge University Press.

Burgoon, J. K. (1991) 'Relational messages of touch, conversational distance, and posture.' Journal of Nonverbal Behavior 15, 233-259.

Canary, D. J., Cody, M. J. and Manusov, V. L. (1994) Interpersonal Communication. New York: St Martin's Press.

Cloven, D. H. and Roloff, M. E. (1991) 'Sense-making activities and interpersonal conflict: Communicative cures for the mulling blues.' Western Journal of Speech Communication 55, 134-158. 
Dementjev, V. V. (2006) Neprjamaja kommunikacija i ee zhanry [Indirect Communication and its Genres]. Moscow: Gnosis.

DeVito, J. A. (2001) The Interpersonal Communication Book. New York: Longman.

Dontcheva-Navratilova, O. and Povolná, R. (2012) 'Introduction.' In: DontchevaNavratilova, O. and Povolná, R. (eds) Discourse Interpretation: Approaches and Applications. Newcastle upon Tyne: Cambridge Scholars Publishing, ix-xiii.

Egides, A. P. (2002) Labirinty obshhenija, ili kak nauchit'sja ladit's ljud'mi [Labyrinth of Communication, or How to Learn to Deal with People]. Moscow: ACT-Press book.

Fairclough N. (2003) Analysing Discourse. New York: Routledge.

Golovaha, E. I. and Panina, N. V. (1989) Psihologija chelovecheskogo vzaimoponimanija. [Psychology of Human Mutual Understanding]. Kiev: Politizdat.

Grice, P. (1975) 'Logic and conversation.' In Cole, P. and Morgan, J. Syntax and Semantics. Vol. 3: Speech acts. New York: Academic Press. 41-58.

Issers, O. S. (2008) Kommunikativnye strategii i taktiki russkoj rechi [Communicative Strategies and Tactics of Russian Speech]. Moscow: Komkniga.

Kecskes, I. (2014) Intercultural Pragmatics. Oxford: Oxford University Press.

Komlósi, L. I. (2012) 'Linguistic context, pragmatic context, mental context: Meaning construction and interpretation via contextualization.' In: Dontcheva-Navratilova, O. and Povolná, R. (eds) Discourse Interpretation: Approaches and Applications. Newcastle upon Tyne: Cambridge Scholars Publishing. 19-38.

Kunicyna, V. N., Kazarinova, N. V. and Pogol'sha, V. M. (2001) Mezhlichnostnoe obshhenie: uchebnik dlja vuzov [Interpersonal Communication: College Textbook]. St Petersburg: Piter.

Lamykin, O. D. (2010) 'Zashhita ot manipuljacij' [Protection from Manipulation]. [Online]. In: Belorussian digital library. Retrieved from http://library.by/portalus/ modules/psychology/readme.php? subaction=showfull\&id=128896093 1 \&archive $=1288969338 \&$ start from $=\&$ ucat $=\& \% 3 \mathrm{E}$

Lemmerman, X. (1999) Uchebnik ritoriki. Trenirovka rechi s uprazhnenijami [Book of Rhetoric. Speech Practice with Exercises]. Moscow: Interexpert.

Leontovich, O. (2014) 'Positive communication: definition and constituent features.' Vestnik of Volgograd State University. Vol. 2. Linguistics 5(24), 123-125.

Leontovich, O. (2002) Russkie i amerikancy: paradoksy mezhkul'turnogo obshhenija: [Russians and Americans: Paradoxes of Intercultural Communication]. Volgograd: Peremena.

McCroskey, J. C. (1997) Willingness to Communicate, Communication Apprehension, and Self-Perceived Communication Competence: Conceptualizations and Perspectives. Cresskill, NJ: Hampton Press.

McMahon, D. and Moyn, S. (2014) 'Ideas still have consequences.' The Chronicle Review, Feb 21, B10-B12.

Moskvin, V. P. (2008) Argumentativnaja ritorika: teoreticheskij kurs dlja filologov [Persuasive Rhetoric: Theory Course for Philologists]. Rostov-on-Don: Phenix.

Motley, M. T. and Molloy, J. L. (1994) 'An efficacy test on a new therapy for public speaking anxiety.' Journal of Applied Communication Research 22, 48-58.

Philips, N. and Hardy, C. (2002) Discourse Analysis: Investigating Processes of Social Construction. London: Sage.

Plano Clark, V. L. and Creswell, J. W. (2008) (eds) The Mixed Methods Reader. Thousand Oaks, California: Sage Publications.

Ponton, D. M. and Larina, T. V. (2016) 'Discourse analysis in the $21^{\text {st }}$ century: Theory and practice.' Russian Journal of Linguistics 20(4), 7-25. 
Tashakkori, A., Teddlie, C. and Teddlie, C. B. (2003) (eds) Handbook of Mixed Methods in Social and Behavioral Research. Thousand Oaks, California: Sage Publications.

Ting-Toomey, S. and Chung, L. C. (2005) Understanding Intercultural Communication. Los Angeles, CA: Roxbury Publishing Company.

Van Dijk, T. A. (2007) 'The study of discourse: An introduction.' In: Van Dijk, T. A. (ed.) Discourse Studies 2. London: Sage, xix- xli.

Verderber, R. and Verderber, K. (2003) Psihologija obshhenija [Psychology of Communication]. St. Petersburg: Prime-Euroznak.

Vygotskij, L. S. (2003) Osnovy defektologii: uchebnik dlja vuzov [Fundamentals of Defectology: College Textbook]. St. Petersburg: Lan'.

Watzlawick, P., Beavin, J. and Jackson, D. (2000) Psihologija mezhlichnostnyh kommunikacij [Psychology of Interpersonal Communication]. St. Petersburg: Rech.

Weaver II, R. L. (1996) Understanding Interpersonal Communication. Boston: Allyn \& Bacon, Inc.

\section{Sources}

Bushnell, C. (2003) Trading up. [Online]. Retrieved from https://www.twirpx.com/ file/829714/

Evans, N. (2005) The Divide. New York: Penguin Books.

Family Jokes [Online]. Retrieved from http://anekdotov.net/anekdot/family/indexpage-75.html

'Flirting Quotes, Sayings, Pick Up Lines' [Online]. (2016) Retrieved from https://www. coolnsmart. com/flirting_quotes/

Kinsella, S. (2011) Remember me? [Online]. Retrieved from https://www.twirpx.com/ file/736959/

Kinsella, S. (2010) Twenties girl. New York: Dial Press.

Meyer, S. (2005) Twilight. New York: Little, Brown and Company.

Sanayev, P. (2015) Pohoronite menya za plintusom [Bury Me behind the Baseboard]. Moscow: ACT.

\section{Filmography}

Benton, R. (Director) (1979) Kramer vs. Kramer [Motion picture]. USA: Columbia Pictures.

Brooks, J. L. (Director) (2004) Spanglish [Motion picture]. USA: Columbia Pictures.

English, D. (Director) (2008) In The Land of The Women [Motion picture]. USA: Picturehouse.

Olga Leontovich, Ph.D., Professor and Chair, Department of Intercultural Communication and Translation of Volgograd State Socio-Pedagogical University, Russia. She has authored over 170 works published in Russia and abroad. She lectured in the USA, China and the UK. She has been a member of the Coordination Committee of the Russian Communication Association since 2000. 
Address: Olga Leontovich, 22 Lenin Prospect, apartment 81, Volgograd 400066, Russia. [e-mail: olgaleo@list.ru]

Marianna Gulyaeva, Ph.D., Associate Professor, Department of Intercultural Communication and Translation of Volgograd State Socio-Pedagogical University, Russia. She has published over 20 works. She participated in a number of international projects and conferences. She is a member of International Pragmatic Association (2015).

Address: Marianna Gulyaeva, 1 Hirosimi str., apartment 172, Volgograd 400050, Russia. [e-mail: maryilya@yandex.ru] 